\title{
EFFECT OF GAMMA IRRADIATION ON THE QUALITY AND MATING COMPETITIVENES OF FRUIT FLIES Bactrocera dorsalis IN THE CAGE SCALE
}

\author{
Indah Arastuti Nasution ${ }^{1}$, Elvinasari ${ }^{2}$, \& Dewi Hastuti ${ }^{2}$ \\ ${ }^{1}$ Center of the Application of Isotope and Radiation, National Nuclear Energy Agency (PAIR-Batan), Indonesia \\ Jl. Lebak Bulus Raya No 49 Pasar Jumat, Jakarta Selatan \\ ${ }^{2}$ Fakultas Pertanian, Universitas Sultan Agung Tirtayasa, Indonesia \\ J1. Raya Jakarta Km 4 Panancangan Cipocok Jaya Kota Serang Banten 42124 \\ E-mail : indah@batan.go.id
}

\begin{abstract}
Effect of gamma irradiation on the quality and mating competitivenes of fruit flies Bactrocera dorsalis in the cage scale. Bactrocera dorsalis is an important fruit fly which attack fruits and vegetables in Indonesia. Sterile Insect Technique (SIT) is a technique of sterilization with gamma irradiation, released as many as $9 \mathrm{x}$ wild population, expected to mate but didn't produce offspring. The research porpuse was to determine the effect of gamma irradiation on the quality and on the mating competitiveness in cage scale. The experimental design was completely randomized design with one factor was gamma irradiation dosee at 6 levels were 0 (control), 30, 50, 70,90 and $110 \mathrm{~Gy}$ as many as 4 replicates. The result that the level of the radiation dose had a significant on the competitiveness and quality included the percentage of pupae became adult (imago), sex ratio, the percentage of fly ability, the number of eggs produced (fecundity) and percentage of hatching eggs. The quality decreased in line with the increasing in radiation dose. The dose level didn't affect the fecundity but affected the mating competitiveness in cage scale. The value total of mating campetitivenes was highest at a dose of 70 Gy treatment which was $0.76(5: 1: 1)$ and 0.79 (10:1:1), followed by dose of 50 Gy which was 0,41 (5:1:1) and 0.50 (10:1:1).
\end{abstract}

Key words: fruit fly Bactrocera dorsalis, irradiation, sterile Insect technique

\begin{abstract}
ABSTRAK
Pengaruh iradiasi gamma terhadap kualitas lalat buah Bactroceera dorsalis dan daya saing kawin dalam skala kurungan. Lalat buah Bactrocera dorsalis merupakan hama penting yang banyak menyerang buah dan sayuran di Indonesia. Pengendalian dengan Teknik Serangga Mandul (TSM) adalah memandulkan dengan iradiasi gamma kemudian dilepas sebanyak 9x populasi alam, dibiarkan kawin tapi tidak menghasilkan keturunan. Tujuan penelitian untuk mengetahui pengaruh iradiasi gamma terhadap kualitas lalat buah B.dorsalis dan terhadap daya saing kawinnya dalam skala kurungan. Rancangan percobaan menggunakan Rancangan Acak Lengkap (RAL) diulang sebanyak 4 kali, dengan dosis iradiasi gamma yaitu 0 (kontrol), 30, 50, 70,90 dan $110 \mathrm{~Gy}$. Hasil pengamatan menunjukkan bahwa perbedaan dosis iradiasi mempunyai efek yang siknifikan terhadap daya saing dan kualitas lalat buah B.dorsalis yang meliputi persentase kemunculan kepompong menjadi lalat buah dewasa (imago), sex ratio, persentase kemampuan terbang, jumlah telur yang dihasilkan (fekunditas) dan persentase penetasan telur. Semakin tinggi dosis radiasi maka kualitas semakin menurun sedangkan tingkat dosis tidak berpengaruh terhadap fekunditas telur. Dosis iradiasi sinar gamma $\left[{ }^{60} \mathrm{Co}\right]$ berpengaruh terhadap daya saing kawin lalat buah $B$. dorsalis dalam skala kurungan. Nilai total daya saing kawin (CV) tertinggi terdapat pada perlakuan dosis 70 Gy yaitu 0,76 (5:1:1) dan 0,79 (10:1:1), diikuti perlakuan dosis 50 Gy yaitu 0.41 (5:1:1) dan 0.500 .50 (10:1:1).
\end{abstract}

Kata kunci: iradiasi, lalat buah Bactrocera dorsalis, teknik serangga mandul

\section{INTRODUCTION}

Fruit fly Bactrocera sp. is one of the important pests in Indonesia (Kalshoven, 1981). This pest attacks many fruit and vegetable plants. The attack of fruit flies on pamelo plants causes farmers to lose $30-60 \%$. Farmers generally still rely on the use of insecticides for pest control. The use of recommended insecticides is still permitted but farmers generally use insecticides exceeding the recommended doses, causing them to be 
unsafe for the environment and commoditie and to become resistant.

Pest control for small-scale gardens is quite safe and effective by using bragging techniques such as in guava and star fruit. For gardens on a large enough scale, bragging technique is ineffective as it requires a lot of time and energy.

Sterile Insect Technique (SIT) is one of the methods that is safe for controlling fruit flies. This technique uses insects maintained in the laboratory. Then the insect is spayed by irradiation at a certain dose according to the target pest and then released to the field as much as a minimum of $9 \mathrm{x}$ the wild population. Irradiated insects will be allowed to mate with insects in nature (normal insects). SIT is one of the potential methods for controlling fruit fly populations. In principle, SIT is the release of sterile male insects to the target area. Sterile male insects will compete with normal male insects to mate with normal females in nature. The mating between sterile mate insects and the normal females is expected not to produce offspring, so the insect population in the target area will decrease (Knipling, 1955; Klassen, 2005; Knipling, 1959).

The control using SIT is effective if there are a large number of normal females who can mate with sterile males so they fail to reproduce (sterile). Mating competitiveness is the ability of all sterile male insects to compete with normal male insects from the target population to get normal female insects. Competitiveness can be categorized in many components such as the ability to survive in the field, the tendency to mate, mating competitiveness and post mating factors. Mating competitiveness shows that normal female insects can receive sterile male insects as partners compared to normal male insects. This suggests that the effects of maintenance systems in the laboratory can bring changes in insect colonies and alter the qualitative patterns of some sexual behavior of insects.

According to Calkins \& Parker (2005), sterility will increase in line with the increasing of irradiation doses but will reduce the quality of irradiated insects. Parameters of quality include flying ability, longevity, startly activity and mating competitiveness. The use of minimum sterilization doses is a strategy used to minimize somatic cell damage (Lance \& McInnis, 2005).

This research aimed to determine the effect of gamma irradiation doses on the quality and mating competitiveness of fruit fly Bactrocera dorsalis in cage scales for the purpose of control with the sterile insect technique.

\section{MATERIALS AND METHODS}

Research Site. The research was conducted at the Entomology Laboratory, Agriculture, Center of the Application of Isotope and Radiation, National Nuclear Energy Agency (PAIR-Batan), Pasar Jumat, South Jakarta. The irradiation process applied gamma chamber irradiator $4000 \mathrm{~A}$ with a radiation source of ${ }^{60} \mathrm{Co}$ at a dose rate of $45.0763 \mathrm{krad} /$ hour. The study began in January to March 2016.

The irradiation treatment of fruit flies was carried out at the pupa stage. The pupa was inserted into a plastic vial. One vial contained 3000 pupae with $4 x$ replicates per dose. Vials containing pupae were then inserted into the gamma ray irradiator machine $\left[{ }^{60} \mathrm{Co}\right]$ with irradiation treatment doses of $0,30,50,70,90$, and $110 \mathrm{~Gy}$. The irradiation treatment was done at 48 hours before the emergence of the pupae to be adults (FAO/ IAEA/USDA (2014).

Quality Testing of Irradiated Fruit Flies. To find out the quality of fruit flies that received irradiation treatment, 100 pupae, which had been irradiated as samples, were placed on a $10 \mathrm{~cm}$ tall paralon tube covered with black cardboard. The paralon tube was covered with sago flour. Sago flour makes the surface of the paralon slippery so that the fruit flies that hatch cannot creep and can only get out of the paralon by flying. The paralon tube was placed in a large cage measuring $60 \times 60 \times 90 \mathrm{~cm}$. After 10 days, observations were made with the following parameters, which are the number of flies that managed to become imago (adult), flight ability, and male : female sex ratio.

The percentage of emergence of adult fruit flies (\% Emergence) was calculated using the equation from Collins et al. (2008):

$$
\% \mathrm{E}=\left(\frac{\sum \mathrm{A}-\left(\sum \mathrm{B}+\sum \mathrm{C}\right)}{\sum \mathrm{A}}\right) \times 100 \%
$$

$\sum \mathrm{A}=$ number of pupae

$\sum \mathrm{B}=$ number of not emerged

$\sum \mathrm{C}=$ number of part emerged

The fruit flies imago that emerged from pupae were differentiated into normal imago with the inability to fly (not fliers) and normal imago with the ability to fly (fliers). The percentage of flying ability of fruit flies (\% Fliers) was calculated using the equation from Collins et al. (2008): 


$$
\% \text { Fliers }=\left(\frac{\sum \mathrm{A}-\left(\sum \mathrm{B}+\sum \mathrm{C}+\sum \mathrm{D}\right)}{\sum \mathrm{A}}\right) \times 100 \%
$$

$\sum \mathrm{A}=$ number of pupae

$\sum B=$ number of not emerged

$\sum \mathrm{C}=$ number of part emerged

$\sum \mathrm{D}=$ number of not fliers

Sex Ratio is done by calculating the ratio of the number of males and females. This observation of sex ratio was done by placing 100 pupae in a petri dish; after 10 days the pupae will become the fruit fly imago and then the number of male imago and female imago were observed. The calculation of sex ratio used the formula of males/total.

Testing the Mating Competitiveness in Fruit Flies. Testing of mating competitiveness in fruit flies B.dorsalis was conducted by mating fruit flies that had been irradiated in small cages measuring $15 \times 15 \times 15 \mathrm{~cm}$. The combination of fruit flies in one cage is as follows Irradiated male + Normal male + Normal female $=0: 1: 1$ Irradiated male + Normal male + Normal female $=1: 0: 1$ Irradiated male + Normal male + Normal female $=5: 1: 1$ Irradiated male + Normal male + Normal female $=10: 1: 1$

The 10-day-old female fruit fly imago will begin laying eggs. The female fruit fly will put the egg in a film bottle that has been perforated. There are wet sponges in the film bottle for the purpose of keeping the eggs moist. The eggs are collected every day and the number of eggs that hatch is calculated.

The total of mating competitiveness of irridated male is calculated using Fried equation (Fried, 1971)

$$
\mathrm{CV}=\frac{(\mathrm{Ha}-\mathrm{Hb})}{(\mathrm{Hb}-\mathrm{Hc})} \times \frac{\mathrm{N}}{\mathrm{S}}
$$

$\mathrm{CV}=$ total of mating competitiveness

$\mathrm{Ha}=\%$ of egg hatching between normal males and normal females

$\mathrm{Hb}=\%$ of egg hatching (normal males vs. irradiated males in normal females)

$\mathrm{Hc}=\%$ of egg hatching between irradiated males and normal females

$\mathrm{N}=$ number of males without irradiation

$\mathrm{S}=$ number of irradiated males

If the total of mating competitiveness of irradiated male is closed to or more than 1.0, it indicates full mating competitiveness and if it is above 0.75 it shows good mating competitiveness. The value between 0.2 and 0.4 is normal for sterile males and $\mathrm{CV}$ value which is less than 0.2 indicates the presence of concerns about competitiveness.

Egg Fecundity and Fertility. Egg fecundity and fertility were carried out by observing eggs which were the result of fruit flies mating of male irradiated to normal females, and normal males to normal females. The calculation of the number of eggs was done carefully using brushes, hand counters and black cardboard. Observation of egg hatching (egg fertility) was conducted by placing fruit fly eggs on a petri dish with black filter paper as the base to make it easier to observe, and saturated cotton water to maintain moisture. Each petri dish contained 100 eggs. Eggs that hatched after 48 hours were observed with a loop or a stereo microscope. Then the number was calculated. Hatched eggs will look more transparent than the unhatched ones. The unhatched eggs look white.

Research Design. The research design used was a Completely Randomized Design (CRD), with 4x replicates. The factor used was the radiation dose (D) with the following levels: D0 : 0 Gy (Control), D1 : 30 Gy, D2 : 50 Gy, D3 : 70 Gy, D4 : 90 Gy, D5 : 110 Gy.

Data Analysis. Data were analyzed using variance analysis ( $\mathrm{F}$ test) at the level of $5 \%$. If the results of variance obtain significant results, then a further test is performed using Duncan Multiple Range Test (DMRT).

\section{RESULTS AND DISCUSSION}

\section{The Effect of Irradiation on the Quality of Fruit}

flies. In Table 1 it can be seen that the percentage of pupae becoming imago (adult) and the flying ability of fruit flies $B$. dorsalis decrease significantly with the increasing of irradiation doses. The percentage of the number of imago reached $95.75 \%$ when there was no irradiation (control) treatment. The highest percentage of imago for irradiation treatment occured at a dose of $30 \mathrm{~Gy}$, which was $87.50 \%$. At the highest irradiation dose, which was at $110 \mathrm{~Gy}$, only $66.25 \%$ of the pupae succeeded in becoming imago. This is significantly different from the treatment at the lowest dose which reached $87.50 \%$.

The highest percentage of flying ability occurred at irradiated pupae at a dose of $30 \mathrm{~Gy}$, which was $74.25 \%$, while the lowest percentage of flight ability 
occurred at the highest dose (110 Gy), which was $42.25 \%$. Guerfali et al. (2011) stated that the higher the irradiation dose, the lower the ability of sterile fruit flies to fly which will make the release of sterile fruit flies less effective. Mahmoud \& Barta (2011) reported that the highest percentage of flying ability in fruit flies $B$. zonata occurred at the dose of $30 \mathrm{~Gy}$, which was $67.5 \%$ and the lowest was at a dose of $90 \mathrm{~Gy}$, which was $59.2 \%$.

The dose of $110 \mathrm{~Gy}$ is not effective for spaying insects. Treatment at a dose of 110 Gy has a low quality both in the percentage of being imago and flying ability. In controlling with SIT, good quality insects are needed, the insects that are able to fly and are able to mate with normal insects in the field. At a dose of $110 \mathrm{~Gy}$, Bourtzis et al. (2014) reported that the increased irradiation rate caused the percentage of the number of pupae that emerged to be adults (imago) in the fruit flyies $B$. cucurbitae to decline. The administration of the lowest irradiation dose of $20 \mathrm{~Gy}$ to $\mathrm{B}$. cucurbitae pupae caused the highest number of imago which was $84.50 \%$ and the lowest number of imago occurred at the highest irradiation dose of 80 Gy which was 57\%. Zahan (2012) reported that the fruit fly $B$. dorsalis had the highest number of imago at the lowest dose of 30 Gy which was $87.67 \%$.
Pupa irradiated by gamma irradiation with a certain dose can damage the body cells which will result in various possibilities of flies that emerge, such as flies that are only able to get out half the body of the pupa (Figure 1A), flies that can get out the entire body of the pupa but die or defect (Figure 1B). Gamma irradiation can also have a more severe effect, which is to make the pupa unable to hatch (Figure 1C). Irradiation exposure often results in changes in the development of insects including ecdysis that generally occurs during the transition period, which is changes in the larval stage to pupa or pupa to imago (Thomas \& Hallman, 2011). Not all pupae affected by gamma irradiation produce flies that experience damage in somatic cells. Those which do not are expected to have damage to the sex cells. If flies that mate have damage to the sex cells then they cannot produce offspring (sterile). Sterility is caused by spermatogonia cells damaged by radiation, which fail to develop into normal spermatids and sperm (Kuswadi, 2011).

Irradiation can cause the imago body shape that has succeeded in undergoing complete eclosion from the pupa to become imperfect, in which the head, legs and abdomen appear shrinked with wings wrinkled or

Table 1. The effect of gamma irradiation $\left[{ }^{60} \mathrm{Co}\right]$ on the quality of fruit flies Bactrocera dorsalis

\begin{tabular}{cccc}
\hline No. & Irradiation doses (Gy) & Percentage of imago (\%) & Flying ability (\%) \\
\hline 1. & 0 & $95.75^{\mathrm{e}}$ & $87.00^{\mathrm{e}}$ \\
2. & 30 & $87.50^{\mathrm{d}}$ & $74.25^{\mathrm{d}}$ \\
3. & 50 & $77.25^{\mathrm{c}}$ & $60.00^{\mathrm{c}}$ \\
4. & 70 & $73.25^{\mathrm{bc}}$ & $52.50^{\mathrm{bc}}$ \\
5. & 90 & $70.75^{\mathrm{ab}}$ & $47.75^{\mathrm{ab}}$ \\
6. & 110 & $66.25^{\mathrm{a}}$ & $42.25^{\mathrm{a}}$ \\
\hline
\end{tabular}

The average percentage followed by the same letter in the same column shows no significant difference based on the Duncan Multiple Range Test at of 5\%.
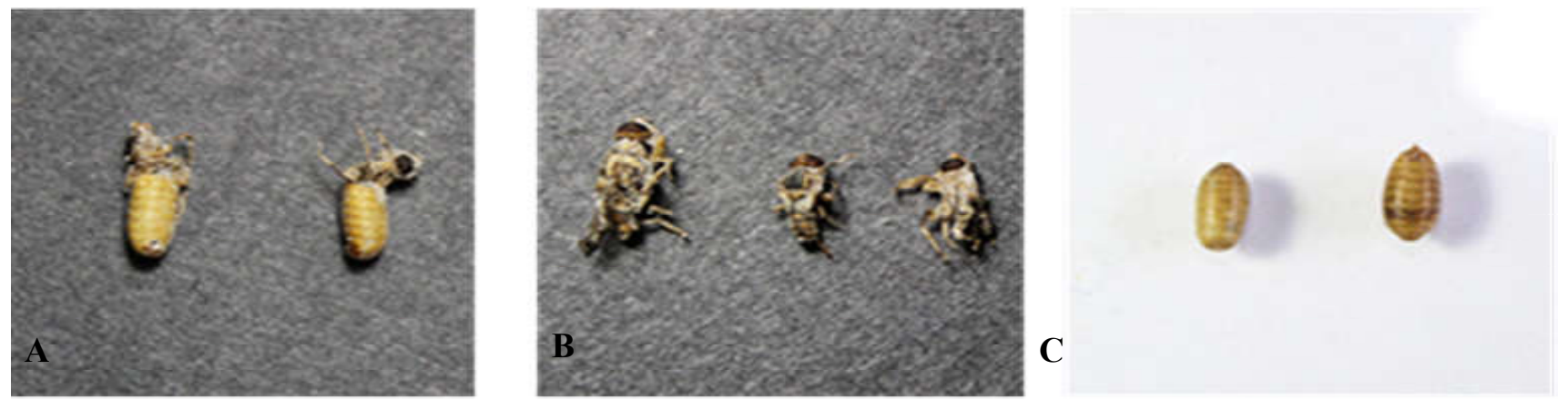

Figure 1. (A) the flies that come out only half the body of the pupae. (B) the flies that are able to get out the entire body of the pupae but die or are defective (C) the pupae do not hatch. 
not perfectly stretched, and a few moments after eclosion, the imago dies.

Effect of Irradiation on Sex Ratio. DMRT results at the level of $5 \%$ on the sex ratio showed that the dose of gamma irradiation significantly affected the sex ratio (male/total) (Table 2). The highest percentage of sex ratio occurred at a dose of $30 \mathrm{~Gy}$, which was $57 \%(0.57)$, followed by doses of $50 \mathrm{~Gy}$ and $70 \mathrm{~Gy}$, which were respectively at $55 \%(0.55)$ and $54 \%(0.54)$. When compared with control of $53 \%(0.53)$, the percentage of sex ratio at high doses ( $>70$ Gy) decreased significantly. The lowest percentage of sex ratio occurred at a dose of $110 \mathrm{~Gy}$, which was $44 \%$ (0.44). Mahmoud \& Barta (2011) reported that the sex ratio tends to decrease gradually in line with the increasing of irradiation doses. Irradiation at the lowest dose of 10 Gy for B. zonata pupae produced the highest percentage of sex ratio which was 50\% (0.50). At higher doses (>30 Gy) the percentage significantly decreased. The lowest ratio which was $44 \%(0.44)$ occurred at the highest dose of $90 \mathrm{~Gy}$.

The release of sterile fruit flies in Indonesia still uses both sexes, male and female. Therefore as an initial step the sex ratio test can be done to minimize sterile females and increase sterile males in the release to the field.

The value of sex ratio that exceeds control will be better. This indicates that there will be less chance of sterile female fruit flies being released in the field or garden. Flores et al. (2014) reported that the release of sterile males by minimizing sterile females significantly increased the efficiency of SIT in controlling fruit flies in Mexico.

Effect of Irradiation on Egg Fecundity and Hatching. The DMRT test results showed that the radiation dose level did not significantly affect the egg fecundity of fruit fly. As for the fecundity of fruit flies that did not undergo irradiation treatment, the results were significantly different compared to those which underwent irradiation. The irradiation dose level did not affect egg production which is the result of mating between irradiated male and normal female fruit flies. Mahmoud \& Barta (2011) reported the same thing for fruit flies B. zonata. Based on the results of testing the number of eggs, it is also known that the higher the radiation dose, the lower the number of eggs despite the slight difference. Zahran et al. (2013) reported that the number of normal female $B$. zonata eggs was reduced when mated with irradiated males at doses of 10, 30, 50, 70 and $90 \mathrm{~Gy}$. According to Collins \& Taylor (2011), irradiated fruit flies paired with normal females have a general tendency at higher doses, i.e. the number of eggs will decrease in spite of the weak effect. Fecundity in $B$. dorsalis is still quite high but this result is still significantly different from fecundity in the control.

From Table 3 it can be seen that the irradiation treatment given has a significant effect on egg hatching. At a dose of 30 Gy egg hatching was $3.5 \%$ and at a dose level of $50 \mathrm{~Gy}$, egg hatching was $0.37 \%$. In the treatment of higher doses, the percentage of hatching reached $0 \%$. The lower the percentage level of hatching the eggs compared to the control, the better (Figure 2). Aspermia is the inability of male insects to produce sperm. According to Kuswadi (2011), irradiation with gamma ray irradiation should be carried out at the pupa stage before emerging to be an adult fly. At that age, the somatic tissue is fully differentiated, and organs such as the head, antenna, wings, legs and abdomen are fully formed. This tissue has stopped growing, and the cells have stopped dividing. Conversely in the reproductive organs, in the testis, genetic cells are actively dividing. The cells that are actively dividing are more sensitive to irradiation and are more damaged by irradiation, than cells that have stopped dividing. When irradiation is carried out, the spermatogenesis process takes place inside the center testis follicle, where the germarium

Table 2. Effect of gamma ray irradiation $\left[{ }^{60} \mathrm{Co}\right]$ on sex ratio of Bactrocera dorsalis

\begin{tabular}{cc}
\hline Irradiation doses $(\mathrm{Gy})$ & Sex ratio \\
\hline 0 & $0.53 \mathrm{~b}$ \\
30 & $0.57 \mathrm{~b}$ \\
50 & $0.55 \mathrm{~b}$ \\
70 & $0.54 \mathrm{~b}$ \\
90 & $0.45 \mathrm{a}$ \\
110 & $0.44 \mathrm{a}$ \\
\hline
\end{tabular}

Numbers followed by the same letters in the same column show no significant difference based on the Duncan Multiple Range Test at of 5\%. 
cells divide into spermatogonia, then divide into spermatocytes, and divide meiosis into spermatids, which at last become sperm. The process of cell division that is currently active is disturbed by the presence of irradiation so that the cells become damaged and testicular growth is disrupted. The sperm cells that are formed become abnormal, causing sterility. Gamma irradiation can also lead to reduced ability of sperm to move to fertilize the egg so that male flies undergo inactivation of sperm. If gamma ray irradiation hits the cell nucleus, it is likely to cause a lethal dominant mutation in the DNA base pair.

Mahmoud \& Barta (2011) reported that the mating of fruit flies $B$. zonata between normal female and irridated male did not affect egg production, but reduced hatchability of eggs. Treatment with a dose of $10 \mathrm{~Gy}$ reduced almost half of the hatching eggs (52.9\%) and the percentage of hatching eggs continued to decrease with the increasing of doses.
The Effect of Irradiation on Total of Mating Competitiveness. Based on the results of the percentage test of observed hatching (EHo) and expected hatching (EHe) for the competitiveness experiments of $B$. dorsalis irradiated fruit flies (Table 4) using the Fried equation (Fried, 1971), it is known that the dose of gamma irradiation $\left[{ }^{60} \mathrm{Co}\right]$ affected $\mathrm{EHo}$ and EHe. The hatched eggs varied significantly depending on the proportion of irradiated male fruit flies in mating competitiveness tests. The percentage of hatching eggs from irradiated male mates and normal females decreases with the increasing of radiation in male ratio. However, the decrease was not prominent for testing with the absence of normal males $(1: 0: 1)$. The total value for mating competitiveness $(\mathrm{CV})$ ranged from $0.21-0.79$. The highest $\mathrm{CV}$ was found in the treatment dose of $70 \mathrm{~Gy}$, which was $0.76(5: 1: 1)$ and $0.79(10: 1: 1)$, followed by the treatment of 50 Gy which was $0.41(5: 1: 1)$ and $0,50(10: 1: 1)$. The total

Table 3. Effects of $\left[{ }^{60} \mathrm{Co}\right]$ gamma ray irradiation on the number of egg and egg hatching of Bactrocera dorsalis

\begin{tabular}{ccc}
\hline Irradiation doses (Gy) & Number of egg (ekor) & Egg hatching (\%) \\
\hline 0 & $1294.50 \mathrm{~b}$ & $87.00 \mathrm{c}$ \\
30 & $1014.50 \mathrm{a}$ & $3.50 \mathrm{~b}$ \\
50 & $984.75 \mathrm{a}$ & $0.37 \mathrm{a}$ \\
70 & $981.25 \mathrm{a}$ & $0.00 \mathrm{a}$ \\
10 & $939.75 \mathrm{a}$ & $0.00 \mathrm{a}$ \\
\hline
\end{tabular}

Numbers followed by the same letters in the same column show no significant difference based on the Duncan Multiple Range Test at of 5\%.

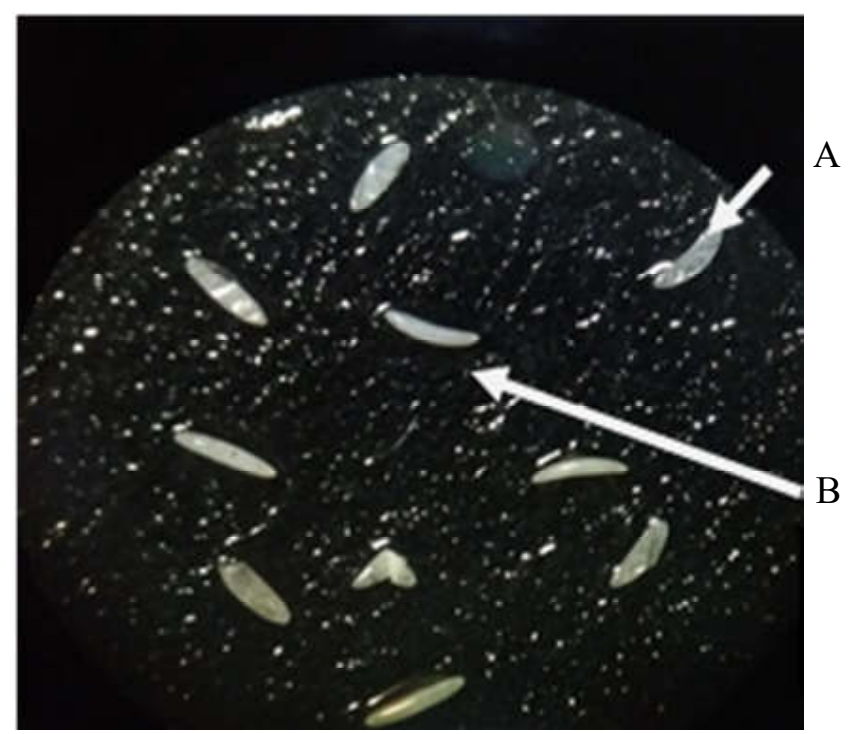

Figure 2. Eggs of Bactrocera dorsalis; (A) eggs which hatche, (B) which do not hatch. 
value of mating competitiveness higher than 0.75 indicates good competitiveness of irradiated males (Fried, 1971).

Mahmoud \& Barta (2011) reported the value of mating competitiveness for male irradiation of $B$. zonata treatment dose of 30 Gy was $0.21(5: 1: 1)$ and 0.37 $(10: 1: 1)$ while for treatment dose of 70 Gy was 0.69 $(5: 1: 1)$ and $0.68(10: 1: 1)$. The two irradiation doses tested showed that male irradiated fruit flies could compete successfully with normal male flies. According to Fried (1971) the inability to mate can occur in male insects. Besides damaging the sex cells irradiation can also damage somatic cells so that insects become weak and unable to undergo good mating. Consequently, irradiated insects had low mating competitiveness compared to normal insects. Somatic abnormalities can be seen from damage to the wing which results in the reduced ability of radiated male to fly, so that the fly does not have the ability to attract attention. This statement was reinforced by de Souza et al. (2015), when approaching male insects of the Tephritidae family involving multimodal signals consisting of movement with the head (visual signal), wing vibrations (sound signals), and release of pheromones (chemical signals). Based on the research of Benelli et al. (2013), about the effect of wing vibrations on mating behavior of fruit flies $B$. oleae, the vibrations of male fruit fly wings play an important role when approaching female fruit flies. Vibration on the wing is a stimulus that will affect the success of fruit fly mating. The importance of the role of wings, in addition to mating behavior, is explained by Benelli et al. (2014) as follows: in a number of species of Tephritidae including fruit flies, male insects have aggressive interactions characterized by reciprocal flapping wings, followed by chasing each other and head butting and attacking with the front foot.

According to Mahmoud \& Barta (2011) in B. zonata the use 90 Gy dose is not used because at this dose sterility is observed in total and the sterile insect technique is not dependent on fully sterile fruit flies. In general, data from the research show that the radiation effect on mating competitiveness of the $B$. dorsalis fruit fly is consistent with results for other Tephritidae fruit fly species. According to these results, considering the need for a balance between sterility (sterility) and mating competitiveness and considering other influential parameters, the best dose of irradiation for $B$. dorsalis pupae is in the range of 50 Gy and 70 Gy treated 48 hours before eclosion. Bactrocera dorsalis fruit flies irradiated at the range of the dose have good quality

Table 4. Effect of [60Co] gamma ray irradiation on EHo, EHe and total of mating competitiveness (CV)

\begin{tabular}{|c|c|c|c|c|c|}
\hline \multirow{2}{*}{$\begin{array}{l}\text { Irradiation } \\
\text { doses (Gy) }\end{array}$} & \multirow{2}{*}{ Observed variables } & \multicolumn{4}{|c|}{ Ratio $\left(\mathrm{S}^{\Uparrow}: \mathrm{N}^{\Uparrow}: \mathrm{N} O\right)^{1}$} \\
\hline & & $0: 1: 1$ & $1: 0: 1$ & $5: 1: 1$ & $10: 1: 1$ \\
\hline \multirow[t]{3}{*}{0} & EHo $(\%)^{2}$ & $87,00^{\mathrm{i}}$ & - & - & - \\
\hline & $\mathrm{EHe}(\%)^{3}$ & - & - & - & - \\
\hline & $\mathrm{CV}^{4}$ & - & - & - & - \\
\hline \multirow[t]{3}{*}{30} & EHo (\%) & - & $3,50^{\mathrm{a}}$ & $45,12^{\mathrm{fg}}$ & $31,31^{\text {de }}$ \\
\hline & $\mathrm{EHe}(\%)$ & - & - & 57,08 & 40,59 \\
\hline & $\mathrm{CV}$ & - & - & 0,34 & 0,36 \\
\hline \multirow[t]{3}{*}{50} & EHo (\%) & - & $0,37^{\mathrm{a}}$ & $39,68^{\mathrm{f}}$ & $23,37^{\mathrm{bc}}$ \\
\hline & $\mathrm{EHe}(\%)$ & - & - & 53,20 & 33,97 \\
\hline & $\mathrm{CV}$ & - & - & 0,41 & 0,50 \\
\hline \multirow[t]{3}{*}{70} & EHo $(\%)$ & - & $0^{\mathrm{a}}$ & $26,50^{\text {cd }}$ & $17,68^{\mathrm{b}}$ \\
\hline & EHe $(\%)$ & - & - & 43,78 & 29,23 \\
\hline & $\mathrm{CV}$ & - & - & 0,76 & 0,79 \\
\hline \multirow[t]{3}{*}{90} & EHo $(\%)$ & - & $0^{\mathrm{a}}$ & $53,81^{\mathrm{h}}$ & $40,18^{\mathrm{f}}$ \\
\hline & $\mathrm{EHe}(\%)$ & - & - & 63,29 & 47,98 \\
\hline & $\mathrm{CV}$ & - & - & 0,21 & 0,23 \\
\hline \multirow[t]{3}{*}{110} & EHo $(\%)$ & - & $0^{\mathrm{a}}$ & $49,12^{\mathrm{gh}}$ & $38,18^{\mathrm{ef}}$ \\
\hline & $\mathrm{EHe}(\%)$ & - & - & 59,94 & 46,32 \\
\hline & $\mathrm{CV}$ & - & - & 0,26 & 0,23 \\
\hline
\end{tabular}

${ }^{1} \mathrm{~S} \hat{O}^{1}$ - irradiated male, NB\&-normal male, N@\&-normal female; ${ }^{2} \%$ hatching of eggs from observations; ${ }^{30} \%$ hatching of eggs calculated based on the Fried equation (1971); ${ }^{4}$ Total of mating competitiveness calculated based on the Fried equation (1971) in Bellini (2013) and Lavy (2016). 
control and good mating competitiveness so that when released in the garden it can compete with normal male fruit flies from the target population and can mate with normal female fruit flies cause no offspring to be produced.

\section{CONCLUSION}

The gamma ray irradiation dose $\left[{ }^{60} \mathrm{Co}\right]$ affects the parameters for the quality of fruit flies, which are the emergency of pupae into imago, sex ratio, flight ability and egg hatching of fruit fly Bactrocera dorsalis. The higher the irradiation dose given, the lower the quality of fruit flies. Fecundity in fruit flies $B$. dorsalis is still quite high although it is still significantly different from fecundity in controls. Gamma ray irradiation dose $\left[{ }^{60} \mathrm{Co}\right]$ affects the mating competitiveness of fruit flies $B$. dorsalis. The highest total value for mating competitiveness $(\mathrm{CV})$ was found in the treatment dose of $70 \mathrm{~Gy}$, which was $0.76(5: 1: 1)$ and $0.79(10: 1: 1)$, followed by a treatment dose of $50 \mathrm{~Gy}$, which was 0.41 $(5: 1: 1)$ and $0.50(10: 1: 1)$.

\section{ACKNOWLEDGMENTS}

The author expresses deepest gratitude to the Head of Center for Application of Isotope and Radiation, National Nuclear Energy Agency, Head of Agriculture Department and Dean of the Faculty of Agriculture, Sultan Agung Tirtayasa University, Serang, Banten. To colleagues in the Entomology group and partners of iradiator operators who have helped a lot for the implementation and smoothness of this research. To all those who can not all be mentioned, the authors say thousands of thanks.

\section{REFERENCES}

Benelli G, Bonsignori G, Stefanini C, Raspi A, \& Canale A. 2013. The production of female sex pheromone in Bactrocera oleae (Rossi) young males does not influence their mating chances. Entomol. Sci. 16(1): 47-53.

Benelli G, Daane KM, Canale A, Niu CY, Messing RH, \& Vargas RI. 2014. Sexual communication and related behaviours in Tephritidae: current knowledge and potential applications for Integrated Pest Management. J. Pest Sci. 87(3): 385-405.
Bourtzis K \& Hendrichs J. 2014. Preface: development and evaluation of improved strains of insect pests for sterile insect technique (SIT) applications. BMC Genetics. 15(Suppl 2): I 1.

Calkins CO \& Parker AG. 2005. Sterile insect quality. In: Dyck VA, Hendrichs J, \& Robinson AS (Eds.). Sterile Insect Technique. Principles and Practice in Area-Wide Integrated Pest Management. pp. 269-296. Springer Netherlands.

Collins SR, Weldon CW, Banos C, \& Taylor PW. 2008. Effects of irradiation dose rate on quality and sterility of Queensland fruit flies Bactrocera tryoni (Froggatt). J. Appl Entomol. 132(5): 398405.

Collins SR \& Taylor PW. 2011. Fecundity, fertility and reproductive recovery of irradiated Queensland fruit fly Bactrocera tryoni. Physiol. Entomol. 36(3): 247-252.

de Souza JMGA, de Lima-Filho PA, Molina WF, de Almeida LM, de Gouveia MB, de Macêdo FP, Laumann RA, \& Paranhos BAJ. 2015. Wing morphometry and acoustic signals in sterile and wild males: implications for mating success in Ceratitis capitata. The Scientific World Journal 2015: 1-9.

FAO/IAEA/USDA. 2014. Product Quality Control for Sterile Mass Reared and Released Tephritid Fruit Flies. Vienna: International Atomic Energy Agency. Austria

Flores S, Montoya P, Toledo J, Enkerlin W, \& Liedo P. 2014. Estimation of populations and sterility induction in Anastrepha ludens (Diptera: Tephritidae) fruit flies. J. Econ. Entomol. 107(4): 1502-1507.

Fried, M. 1971. Determination of sterile-insect competitiveness. J. Econ. Entomol. 64(4): 869872.

Guerfali MM, Parker A, Fadhl S, Hemdane H, Raies A, $\&$ Chevrier C. 2011. Fitness and reproductive potential of irradiated mass-reared mediterranean fruit fly males Ceratitis capitata (Diptera: Tephritidae): lowering radiation doses. Fla. Entomol. 94 (4): 1042-1050.

Kalshoven IGH. 1981. The Pests of Crops in Indonesia. Revised and Tranlated By PA Van der laan. P.T. Ichtiar Baru-Van Hoeve. Jakarta. 
Klassen W. 2005. Area-wide integrated pest management and the strile insect technique. In: Dyck VA, Hendrichs J, \& Robinson AS (Eds.). Sterile Insect Technique.Principles and Practice in Area-Wide Integrated Pest Management. pp. 39-68. Springer Netherlands.

Knipling EF. 1955. Possibilities of insect control or eradication through the use of sexually sterile males. J. Econ. Entomol. 48(4): 459-462.

Knipling EF. 1959. Sterile-male method of population control. Science 130(3380): 902-904.

Kuswadi AN. 2011. Kerusakan morfologis dan histologis organ reproduksi lalat buah Bactrocera carambolae (Drew \& Hancock) (Diptera; Tephritidae) jantan yang dimandulkan dengan iradiasi gamma. J.Ilmiah Aplikasi Isotop dan Radiasi. 7(1): 1-10.

Lance DR \& McInnis DO. 2005. Biological basis of the sterile insect technique. In: Dyck VA, Hendrichs J, \& Robinson AS (Eds.). Sterile Insect Technique. Principles and Practice in Area-Wide Integrated Pest Management. pp. 69-94. Springer Netherlands.
Mahmoud MF \& Barta M. 2011. Effect of gamma radiation on the male sterility and other quality parameters of peach fruit fly, Bactrocera zonata (Saunders) (Diptera: Tephritidae). Hort. Sci. 38(2): 54-62.

Thomas DB \& Hallman GJ. 2011. Developmental arrest in Mexican fruit fly (Diptera: Tephritidae) irradiated in grapefruit. Ann. Entomol Soc Am. 104(6): 1367-1372.

Zahan A. 2012. Development of Artificial Larval Diet and Optimization of Sterile Male Ratio of Oriental Fruit Fly, Bactrocera dorsalis (Hendel). Thesis. Department of Entomology Sher-e-Bangla Agricultural University. Bangladesh.

Zahran NFM, Hegazy GM, Salem HM, Elsayed W, \& Mahmoud YA. 2013. The effect of gamma radiation on some biological aspects of peach fruit fly, Bactrocera zonata (Saunders). J. Nucl. Tech. Appl. Sci. 1(1): 91-100. 